\title{
THE STUDY OF STRUCTURAL CHANGES DUE TO THE COVID-19 PANDEMIC ACCORDING TO THE ACTIVITIES' INDICATORS OF SMALL AND MEDIUM ENTERPRISES
}

\author{
NILA KHRUSHCH \\ Khmelnytskyi National University \\ ORDID: https://orcid.org/0000-0002-9930-7023 \\ e-mail: nila.ukr@gmail.com
}

Small and medium-sized enterprises are an important component of the economic system of most countries, providing employment and income to a significant proportion of the population, economic and social transformation. At the same time, they are not so dependent on foreign markets, currency fluctuations, flexibly adapt to changing market conditions. Small and medium-sized businesses also play an important role in the domestic economy. They form a significant part of local budget revenues, ensuring the creation of new jobs; solving the problem of overcoming unemployment; provide support and development of the middle class in society; rapid adaptation to market changes, new circumstances. The COVID-19 pandemic has slowed down businesses of various sizes and types in various ways. Small and medium-sized enterprises operating in various sectors of the economy suffered the most. This study aims to examine the impact of the COVID-19 pandemic on the functioning of small and medium-sized enterprises and the change in regional structure in terms of their activities' indicators. We applied a research methodology with a critical review of the available publications for this sector of the economy. To solve the identified problem, we used the k-means clustering method, which is an iterative procedure for finding groupings of objects in the initial indicators" space. As a result of the calculations, the regions of Ukraine were distributed among four clusters. We described each cluster. Studies have shown that in 2020 there were no significant changes in the cluster structure of regions. This leads to the conclusion that the impact of the pandemic is equally evident in all regions. We also analyzed the measures of the government of the country, aimed at supporting the activities of small and medium enterprises, reducing losses and risks of closure from restrictive measures.

Keywords: Covid-19, small and medium-sized enterprises, regional structure, clustering, $k$-means method.

\section{DOI: $10.31891 / \mathrm{mdes} / \mathbf{2 0 2 1 - 1 - 1}$}

\section{PROBLEM DESCRIPTION}

Small and medium-sized enterprises (SMEs) are an important part of the economic system of most countries. They provide employment and income for a significant proportion of the population, their economic and social transformation, contributes to economic diversification and social stability. Such enterprises are less dependent on foreign markets, currency fluctuations, and flexibly adapt to changing market conditions. According to the International Monetary Fund [1], SMEs account for $99 \%$ of all firms, more than $60 \%$ of jobs, and more than $50 \%$ of sales in most economies.

A key challenge facing the world is the Covid-19 pandemic, which has caused a global economic crisis and has significantly reduced the income and employment levels of many companies. The crisis consequences were the suspension of economic activity or a significant reduction in the functionality of many businesses and the growing threat of temporary or permanent disappearance of business. SMEs are the most vulnerable group of businesses, as their resources are often insufficient to deal with crises in the long run. The difficulty of adapting to new economic conditions also manifested itself in the impossibility of rapid reformatting of production processes. SMEs have less access to financial resources due to low attractiveness for investors and limited lending opportunities. This necessitated complex decisions as the risk of loss of solvency increased and the level of financial stability decreased, which were often aimed at non-restrictive, temporary, and in some cases complete cessation activities. Under such conditions, it is important to assess trends in SME performance to develop the necessary measures at the national level to support the activities of such enterprises.

\section{LITERATURE REVIEW AND GOALS FORMULATION}

The issue to assess the SMEs' functioning in the context of the Covid-19 pandemic is the subject of discussion by a wide range of researchers from almost all countries. Study [2] presents data on the impact of Covid-19 on the activities of 4467 companies from 132 countries, which were collected in the period from April 21 to June 2, 2020. The results of the presented analysis show that $55 \%$ of respondents confirmed that the Covid-19 pandemic had a strong impact on their activities. About two-thirds of micro and small firms reported that the crisis had a strong impact on their business operations, compared with about $40 \%$ of large firms. One-fifth of SMEs said they risked stopping forever for three months. In Africa, two out of three companies reported being severely affected by COVID-19, mainly due to declining sales (75\%) and/or difficulties in accessing input (54\%). Service companies have suffered the most worldwide. For example, 
in the area of housing and food, $76 \%$ of firms surveyed said that partial and complete blockades had a strong impact on their business operations.

Paper [3] presents the results of the short- and medium-term impact of COVID-19 restrictions on SME activities, based on two waves of telephone interviews with a previously surveyed large sample of China's SMEs. It is noted that the outbreak of COVID-19 forced the government to take tough measures to block the activities of SMEs, which led to significant losses. Due to problems with logistics blocs, labor shortages, and falling demand, 80\% of SMEs were temporarily closed until February 2020 during the first wave of the pandemic. After the containment at COVID-19 in April, the authorities largely relaxed the restrictions and blockade. Thus, most small and medium-sized enterprises were opened until the second round of surveys in May. However, many firms, especially exporting firms, operated in part, mainly due to inadequate demand. Moreover, about $19 \%$ of registered enterprises and $25 \%$ of self-employed enterprises closed forever between the two waves of surveys. Study [4] conducted to assess the impact of the second wave of the pandemic on the activities of SMEs in the United States, showed as of February 1, 2021 , that total small business income decreased by $30.9 \%$ compared to January 2020, largely due to lower consumer spending. Loss of income has led to unemployment, with the highest risk of unemployment among low-paid workers. SMEs in areas vulnerable to extreme weather and climate are faced with potentially challenging events as they prepare for or respond to natural disasters during a pandemic.

According to the International Monetary Fund [1], the increasing solvency risks of SMEs raise important concerns about economic growth, jobs, and the financial stability of creditors. Even with a strong economic recovery, about one-fifth of SMEs may have negative net equity by the end of 2021 if they don't close earlier, and other insolvency rates may deteriorate. Deterioration of the balance sheet of SMEs can lead to the risk of losing up to $10 \%$ of their jobs, and $10 \%$ of debt risks not being repaid. It should also be noted the lack of financial resources. A significant proportion of small and micro enterprises rely on personal savings and limited trade credit, as most major commercial banks are reluctant to provide them.

Company "Info Sapiens", commissioned by the Center for International Private Enterprise, conducted a large-scale survey of managers, owners of micro, small and medium-sized businesses in Ukraine [5]. The results showed that if at the end of the first quarter of 2020 most enterprises characterized their stage of development as "stable", then by the middle of the third quarter (at the time of the survey) the share of "stable" enterprises halved (from $66 \%$ to $32 \%$ ). The share of enterprises at the stage of recession or even closure increased by an order of magnitude (from 7\% to 59\%). The most pessimistic attitudes of microbusiness representatives - $60 \%$ of respondents assess the current situation as a decline, while among medium-sized businesses the share of such estimates is $42 \%$. The share of enterprises that assess their stage of development as "growth" has also decreased significantly (from $25 \%$ to $5 \%$ ). Similar results are presented in studies for other countries [6-14].

Finding ways out of the current situation, developing strategies for SMEs operation that will allow them to support their business and suffer minimal losses due to the Covid-19 pandemic, presented in [1537]. According to scholars' point of view, one of the most important factors that will contribute to the achievement of these goals is the support of small and medium-sized businesses by the state [15-23]. Inclusive policies to assist SMEs, such as social security, financial support programs, temporary tax incentives, and tax deferrals, be more effective than other targeted policies, such as credit guarantees or programs aimed at the employment of employees that are more effective large campaigns. Paper [24] provides examples of successful SME support policies in countries such as South Korea, the United Kingdom, the United States, and the French Republic. Current issues of state support for small businesses in Ukraine are posted on the web portal [25]. In particular, they are related to the provision of financial state support to small and medium enterprises through the program of soft loans "5-7-9"; receiving one-time financial assistance for UAH 8.000; a moratorium on tax audits; tax holidays; partial repayment of tax debt.

According to scholars' opinion, the use of risk management technologies and crisis management strategies is very important in this case [26-30]. However, as rightly noted by G. B. Sylvana [28], the concepts of risk management are not widely used in the practice of managing small and medium-sized businesses, due to limited resources.

E. Hadiyati and F. Hendrasto [31] based on the example of Indonesia's SMEs design a business marketing strategy based on the tools of SWOT analysis and evaluation of IFAS and EFAS. According to the authors, the proposed growth strategy focuses on using the company's strengths to take advantage of various business opportunities during the Covid-19 pandemic.

An effective tool to support the SMEs' activities is their reorientation to the provision of new services that are in demand in a pandemic, and the use of new forms of business, in particular, the use of 
online and digital technologies [32, 33]. Small and medium-sized enterprises are generally less inertial, and this reorientation is usually faster and less costly.

Providing the analytical processing of available data is Important in processes of decision-making and developing strategic plans, in which much attention is paid to the methods of economic and mathematical modeling. The paper [36] presents the results of an expert survey of the impact of COVID-19 on sales. Based on the results of data processing, a conclusion was made on the negative impact of the pandemic on cash flows and business profitability. K. Grondys with co-authors [37] assessed the most important risks by using analysis of variance in the SPSS system. The initial data were the results of empirical research conducted on small and medium enterprises in Poland. It was found that during a pandemic, the level and type of risk are the same in all surveyed enterprises. They are often threatened by strong competition in the industry, rising energy prices, and declining profits.

It should be noted that the analysis of the impact of the pandemic on the activities of domestic SMEs, studies of changes in the structure of regions on the indicators of their activities are currently not sufficiently reflected.

The purpose of this paper is to study the impact of the Covid-19 pandemic on the activities of SMEs by region and to identify structural changes in regional development in the context of SMEs. To achieve this goal, we will group the regions by indicators of SME development and explore the change in the clusters' structure.

\section{RESULTS AND DISCUSSIONS}

Given the multidimensionality of the description of the activities of SMEs, to solve the problem of grouping SMEs by indicators of their activities, we use a political approach. Under such conditions, all indicators simultaneously affect the results of grouping. In addition, they are considered equally important for the final result. The implementation of the political approach is successfully carried out in the framework of cluster analysis. Even though clustering methods are heuristic procedures that do not have a statistical basis, they are quite widely used to solve problems of grouping regions [38-40]. It should also be noted that applying different clustering methods to the same data can lead to different results. In this study, we use the k-means method for clustering. Its feature is that the number of clusters is determined in advance, and their content is set during the iterative clustering procedure. The main idea of the k-means algorithm is that the data is arbitrarily divided into clusters, after which iteratively lists the center of mass for each cluster obtained in the previous step. Next, the observation objects are divided into clusters again according to which of the new centers was closer to the corresponding object. The purpose of the algorithm is to divide the original set of observation objects by a predetermined number $\mathrm{k}$ of clusters so that each observation belongs to exactly one cluster located at the smallest distance from the center of this cluster. At the same time, the distance to the centers of other clusters should be greater.

Consider the application of this procedure to the grouping of Ukraine's regions by indicators of SME activities. As the initial set of indicators, we choose the following ones:

$X_{1}$ - the number of medium-sized businesses per 10 thousand people of the current population;

$X_{2}$ - the number of small businesses (including micro-entrepreneurship) per 10 thousand people of the current population;

$X_{3}$ - the share of the volume of sold products (goods, services) of medium-sized enterprises (in the total volume of sold products (goods, services) by business entities;

$X_{4}$ - the share of sales of products (goods, services) of small businesses (including microenterprises) in the total sales of products (goods, services) by businesses.

The information base for the calculations was the data of the Ministry for Communities and Territories Development of Ukraine [41]. For the convenience of representation of regions at carrying out calculations, we assign to each region the corresponding code (Table 1). The initial indicators' values are shown in Table 2.

Table 1

Correspondence between the name of Ukraine's region and its code designation

\begin{tabular}{|l|c|c|c|c|c|}
\hline Code & Region & Code & Region & Code & Region \\
\hline C_01 & Vinnytsia & C_09 & Kyiv & C_17 & Sumy \\
\hline C_02 & Volyn & C_10 & Kyrovohrad & C_18 & Ternopil \\
\hline C_03 & Dnipro & C_11 & Luhansk & C_19 & Kharkiv \\
\hline C_04 & Donetsk & C_12 & Lviv & C_20 & Khorson \\
\hline C_05 & Zhytomyr & C_13 & Mykolaiv & C_21 & Cherkasy \\
\hline C_06 & Zakarpattia & C_11 & Odesa & C_22 & Chernivtsi \\
\hline C_07 & Zaporizhzhia & C_15 & Poltava & C_23 & C_24 \\
\hline C_08 & Ivano-Frankivsk & C_16 & Rivne & Chernihiv \\
\hline
\end{tabular}


Table 2

Initial data to make the calculation

\begin{tabular}{|c|c|c|c|c|c|c|c|c|}
\hline \multirow{2}{*}{ Region } & \multicolumn{2}{|c|}{$X_{1}$} & \multicolumn{2}{|c|}{$X_{2}$} & \multicolumn{2}{|c|}{$X_{3}$} & \multicolumn{2}{|c|}{$X_{4}$} \\
\hline & 2019 & 2020 & 2019 & 2020 & 2019 & 2020 & 2019 & 2020 \\
\hline C_01 & 3.6 & 4.0 & 434.2 & 448.2 & 41.3 & 41.9 & 36.8 & 35.8 \\
\hline C_02 & 3.2 & 3.8 & 375.2 & 394.2 & 56.4 & 58.2 & 21.7 & 22.9 \\
\hline C_03 & 4.2 & 4.6 & 431.8 & 460.4 & 25.9 & 25.2 & 19.5 & 20.4 \\
\hline C_04 & 1.2 & 1.4 & 147.3 & 155.5 & 19.5 & 21.9 & 11.4 & 13.2 \\
\hline C_05 & 3.4 & 3.7 & 399.3 & 416.3 & 43.5 & 42.3 & 37.1 & 39.0 \\
\hline C_06 & 2.1 & 2.4 & 405.4 & 400.7 & 43.7 & 40.2 & 46.6 & 47.3 \\
\hline C_07 & 3.6 & 3.9 & 430.1 & 448.1 & 23.4 & 23.6 & 24.3 & 27.7 \\
\hline C_08 & 2.5 & 2.6 & 379.9 & 398.9 & 38.3 & 36.2 & 35.9 & 33.0 \\
\hline C_09 & 5.6 & 6.0 & 568.9 & 609.2 & 38.4 & 37.6 & 28.6 & 28.8 \\
\hline C_10 & 3.7 & 4.5 & 380.0 & 401.4 & 50.4 & 48.3 & 44.1 & 41.6 \\
\hline C_11 & 1.0 & 1.0 & 100.2 & 104.2 & 33.2 & 37.8 & 41.3 & 42.8 \\
\hline C_12 & 3.9 & 4.3 & 453.5 & 489.7 & 44.9 & 42.3 & 34.7 & 34.5 \\
\hline C_13 & 3.1 & 3.6 & 479.8 & 496.7 & 30.3 & 32.6 & 34.3 & 35.1 \\
\hline C_14 & 3.8 & 4.1 & 548.7 & 574.3 & 40.1 & 37.7 & 36.8 & 37.8 \\
\hline C_15 & 4.5 & 5.0 & 430.0 & 459.0 & 36.1 & 38.3 & 23.4 & 24.5 \\
\hline C_16 & 2.9 & 3.3 & 338.7 & 358.0 & 44.3 & 46.4 & 42.2 & 43.3 \\
\hline C_17 & 3.5 & 3.9 & 367.9 & 383.7 & 51.5 & 51.2 & 32.8 & 34.2 \\
\hline C_18 & 2.6 & 3.0 & 349.2 & 359.8 & 51.3 & 51.4 & 40.3 & 42.5 \\
\hline C_19 & 4.6 & 4.9 & 568.9 & 605.4 & 43.2 & 42.7 & $\begin{array}{l}41.7 \\
\end{array}$ & 41.5 \\
\hline C_20 & 2.9 & 3.0 & 422.9 & 442.3 & 40.3 & 41.5 & 49.1 & 50.9 \\
\hline C_21 & 3.1 & 3.5 & 479.3 & 499.7 & 49.4 & 45.6 & 38.5 & 38.7 \\
\hline C_22 & 4.1 & 4.6 & 445.2 & 466.4 & 41.5 & 45.5 & 31.2 & 29.4 \\
\hline C_23 & 2.1 & 2.4 & 479.0 & 493.5 & 38.6 & 42.8 & 57.0 & 57.2 \\
\hline C_24 & 3.9 & 4.5 & 385.9 & 408.5 & 49.4 & 49.9 & 35.5 & 36.8 \\
\hline
\end{tabular}

We perform calculations using the Statistica program in Russian localization and choose the number of clusters $\mathrm{k}=4$. The results of clustering are presented in Figures 1 and 2.

\begin{tabular}{|l|c|}
\hline & \multicolumn{2}{|l|}{$\begin{array}{l}\text { Элементы кластера номер 1 (Таблии } \\
\text { и расстояния до центра кластера. } \\
\text { Кластер содержит 8 набл. }\end{array}$} \\
\cline { 2 - 3 } Наблюд. & объедин. \\
\hline C_3 & 0,755627 \\
\hline C_7 & 0,785124 \\
\hline C_9 & 0,796577 \\
\hline C_13 & 0,613649 \\
\hline C_14 & 0,554229 \\
\hline C_15 & 0,450912 \\
\hline C_19 & 0,847222 \\
\hline C_22 & 0,417990 \\
\hline
\end{tabular}
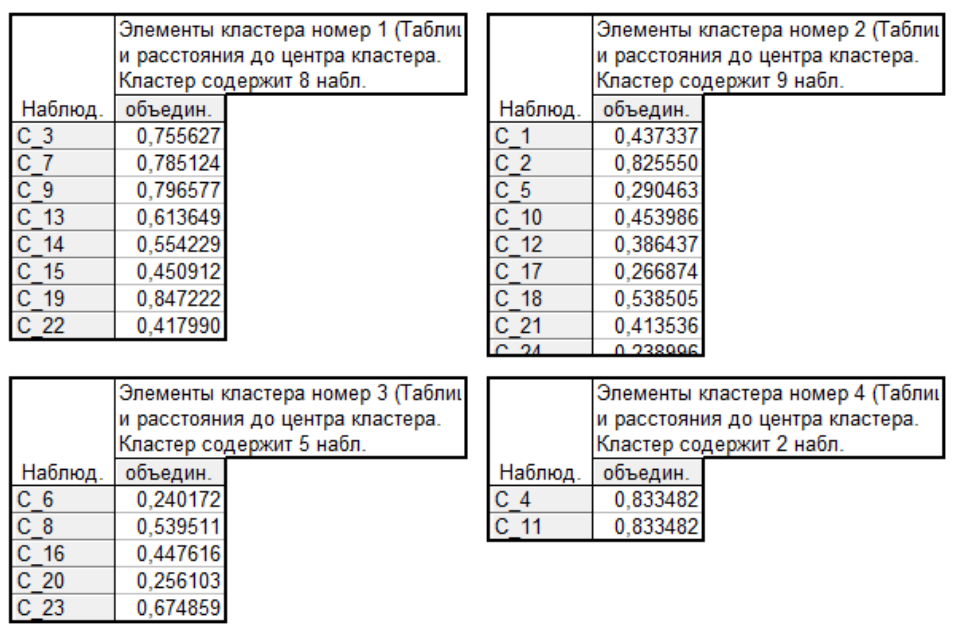

Figure 1. Clustering of Ukraine's regions for data 2019

Let us compare the cluster structures obtained according to the data of 2019 and data of 2020. As we see, the first cluster in 2019 included Mykolaiv, Odesa, Dnipro, Poltava, Zaporizhzhia, Kharkiv, Kyiv, Cherkasy regions. These are regions with the relatively high development of small and medium enterprises, which is reflected in the rather high values of indicators shown in Table 2. The second cluster includes Vinnytsia, Volyn, Zhytomyr, Sumy, Ternopil, Khmelnytskyi, Kyrovohrad, Lviv, Chernihiv regions. The group of regions can be described as having indicators above the average level. The third group includes Rivne, Zakarpattia, Ivano-Frankivsk, Kherson, and Chernivtsi regions. This group of regions has indicators below the average level. And the last cluster was formed by Donetsk and Luhansk regions. It is known that these regions are the most depressed and have a relatively low level of SME development. 


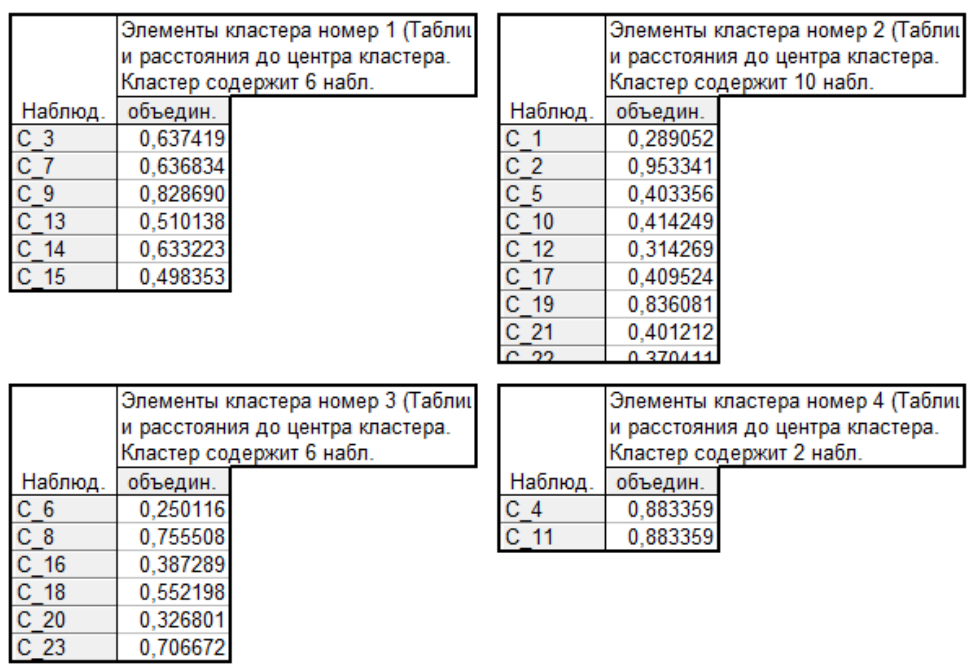

Figure 2. Clustering of Ukraine's regions for data 2020

Analysis of the cluster structure of regions according to 2020 showed that from the first group two regions: Kharkiv and Cherkasy moved to the second group with values above the average level. This is due to a decrease in the share of sales of SMEs, although the number of such entities has increased compared to the previous year. From the second group, the Ternopil region moved to the group of regions with a below-average level of SME development. This is because this region was one of the first in Ukraine to be classified as a "red" zone and was there for a long time, which primarily limited the activities of small and medium enterprises. The fourth group of regions remained unchanged.

However, analyzing the changes in the regional structure of Ukraine in terms of SME development, it can be stated that the Covid-19 pandemic did not have a significant impact on changes in this structure. That is the negative impact of quarantine restrictions on the activities of SMEs equally evident in almost all regions.

It should be noted that the government is taking certain measures to support the activities of SMEs. This was facilitated by the program "Affordable loans 5-7-9\%." Thus, only for the first three days of 2021 such loans were issued in the amount of UAH 338 million, including through refinancing at $0 \%$ - UAH 202 million [42]. With the support of the EU and the German government, the COVID-19 business clinic has been launched in Ukraine under the EU4Business: Competitiveness and Internationalization of SMEs project. Their activities are aimed at assisting domestic SMEs to meet the challenges posed by the COVID19 pandemic. More than UAH 10 million have been allocated for the implementation of this initiative [43].

The need for further development of the IPU is also reflected in the State Strategy for Regional Development for 2021-2027 [44], where among the operational strategy's goals and main objectives are state support for small and medium enterprises, interest compensation on loans to small and medium enterprises, create jobs in problem areas, promotion for the formation of business development infrastructure, in particular, business centers, business incubators, and others.

\section{CONCLUSIONS}

Thus, the study showed that the problem of the functioning of small and medium enterprises in a pandemic is the subject of discussion by a wide range of researchers. An analysis of the publications showed that the problems faced by SMEs are typical of both developed and developing countries. To assess the impact of the pandemic on the development of small and medium enterprises in Ukraine, we conducted a clustering of regions of Ukraine according to the Ministry for Communities and Territories Development of Ukraine. The results of the research did not show significant changes in the regional structure in terms of SME performance. This led to the conclusion that the impact of the pandemic was equally evident in all regions.

\section{ACKNOWLEDGMENTS}

This study was supported by the State budget project of Khmelnytskyi National University, project's registration number $0120 \mathrm{U} 102123$. 


\section{REFERENCES}

1. Insolvency Prospects Among Small-and-Medium-Sized Enterprises in Advanced Economies: Assessment and Policy Options. International Monetary Fund / Diez F. J. et.al. Staff Discussion Notes. 2021. Iss. 002. DOI: https:// doi.org/10.5089/9781513574561.006. URL: https://is.gd/9BqpJx (accessed: 26.05.2021)

2. SME Competitiveness Outlook 2020: COVID-19: The Great Lockdown and its Impact on Small Business. Geneva: International Trade Centre. 2020. 172 p. URL: https:/ / is.gd/DZFS3Z (accessed: 26.05.2021)

3. The impact of COVID-19 on small and medium-sized enterprises (SMEs): Evidence from two-wave phone surveys in China / Dai R. et. al. China Economic Review. 2021. Vol. 67. Paper 101607. ISSN 1043-951X

4. Longitudinal Study of Complex Event Resilience of Small- and Medium-Sized Enterprises: Natural Disaster Planning and Recovery During the COVID-19 Pandemic (Wave 2). Helgeson J. F. et. al. Doi: DOI: http:/ / dx.doi.org/10.6028/nist.sp.1267. URL: https://is.gd/xzYV7s (accessed: 25.05.2021) 26.05.2021)

5. Report on the study of micro, small and medium enterprises (in Ukrainian). URL: https://is.gd/dS17IE (accessed:

6. Shafi M., Liu J., Ren W. Impact of COVID-19 Pandemic on Micro, Small, and Medium-Sized Enterprises operating in Pakistan. Research in Globalization. 2020. DOI: https://doi.org/10.1016/j.resglo.2020.100018

7. Mwenda Mutwiri N. (2021). Covid-19 financial distancing for MSMEs in Kenya. International Journal of Research in Business and Social Science. 2021. Vol. 10(3). Pp. 357-362. https://doi.org/10.20525/ijrbs.v10i3.1110 URL: https://is.gd/1agaOI (accessed: 26.05.2021)

8. COVID-19 Pandemic and Its Implications on Small and Medium Enterprises (SMEs). Operations in Zambia / Mwaanga C. et.al. Journal of Business Administration Research. 2021. Vol. 10. No. 1. Pp. 32-40 DOI: https://doi.org/10.5430/jbar.v10n1p32

9. COVID-19: Implications on Small and Medium Enterprises (SMEs) in Japan. International Journal of East Asian Studies / Alias A. et.al. 2021. Vol. 10. No. 1. Pp. 157-174. Special Issue on Covid-19 and Japan DOI: https:// doi.org/10.22452/IJEAS.vol10no1.10. URL: https://cutt.ly/2nmdDvu (accessed: 26.05.2021)

10. Bularafa B. A., Adamu, U. G. Effect of COVID-19 Pandemic on SME Performance in Nigeria. Advanced International Journal of Business, Entrepreneurship and SMEs, 2021. Vol. 3 (7). Pp. 75-92. DOI: 10.35631/AIJBES.37007. URL: https://is.gd/vb1Dcx (accessed: 28.05.2021)

11. , Zakharkin, O., Zakharkina, L., Bilous, Y. (2020). The impact of the covid-19 pandemic on business activities in Ukraine / Boronos V. el.al. Health Economics and Management Review. 2020. Vol. 1(1). Pp. 76-83. DOI: https:// doi.org/10.21272/hem.2020.1-07

12. Krasota O., Kiriev I. Features of small entrepreneurship development under macroeconomic stability violations. Efektyona ekonomika. 2021. Vol. 2 (in Ukrainian). DOI:10.32702/2307-2105-2021.2.98. URL: http:/ / www.economy.nayka.com.ua/?op=1\&z=8671 (accessed: 26.05 .2021 ).

13. Vagner I., Demko I. The impact of Covid-19 on the economic development of small and medium-sized business in Ukraine. Bulletin of the University of Banking. 2020. №1(37). Pp. 59-66

14. Saturwa H., Suharno S., Ahmad A. The impact of Covid-19 pandemic on MSMEs. Jurnal Ekonomi Dan Bisnis. 2021. Vol. 24(1). Pp. 65-82. DOI: https:// doi.org/10.24914/jeb.v24i1.3905. URL: https://is.gd/e1U1Cp (accessed: 28.05.2021)

15. Hadi S., Supardi, S. Revitalization strategy for small and medium enterprises after Corona virus disease pandemic (Covid-19) in Yogyakarta. Journal of Xi' an University of Architecture \& Technology. 2020. Vol. 12. Pp. 4068-4076

16. Startups in times of crisis - A rapid response to the COVID -19 pandemic / Kuckertz A. et.al. Journal of Business Venturing Insights. 2020. Vol. 13. Paper e00169. DOI: https:// doi.org/10.1016/j.jbvi.2020.e00169

17. Sudarmo S. Understanding the challenges and opportunities of micro, small, and medium enterprises during COVID19 pandemic in Indonesia: a systematic review. International Journal of Business, Economics \& Management. 2021. Vol. 4(1). Pp. 54-62. DOI: https://doi.org/10.31295/ijbem.v4n1.825

18. Zaazou Z.A., Salman Abdou D. Egyptian small and medium sized enterprises' battle against COVID-19 pandemic: March - July 2020. Journal of Humanities and Applied Social Sciences. 2021. Vol. ahead-of-print No. ahead-of-print. DOI: https:// doi.org/10.1108/JHASS-09-2020-0161

19. Mustapa A.N., Mohamad A. Malaysian Government Business Support and Assistance for Small and Medium Enterprises: A Case of COVID-19 Pandemic Crisis / Sergi, B.S., Jaaffar A.R. (Ed.). Modeling Economic Growth in Contemporary Malaysia (Entrepreneurship and Global Economic Growth). 2021: Bingley, Emerald Publishing Limited. Pp. 291-305.DOI: https://doi.org/10.1108/978-1-80043-806-420211022

20. Antoni A. Funding and management support for recovering of micro, small and medium enterprises during disruption of COVID-19. International Journal of Business, Economics $\mathcal{E}$ Management. 2021. Vol. 4(1). Pp. 28-34. DOI: https://doi.org/10.31295/ijbem.v4n1.725. URL: https://is.gd/18iuvG (accessed: 27.05.2021).

21. Diakunovskyi $\mathrm{O}$. As to the state supporting for small and medium enterprises in the condomination of a coronavirus disease pandemic (Covid-19) in the republic of Poland and Ukraine. Knowledge, Education, Law, Management. 2020. № 3 (31). Vol. 1. Pp. 181-189

22. Heiko T. Priorities of entrepreneurship development in Ukraine in the conditions of the COVID-19 pandemic and post-quarantine period. Socio-economic research bulletin. 2020. No. 2 (73). Pp. 62-71.

23. Okhrimenko O., Zrobok O. Evaluation of the effectiveness of national policies of minimization of consequences COVID-19 pandemics. Technology audit and production reserves. 2021. Vol. 1(4(57)). Pp. 38-44. URL: https://is.gd/mPHvR2 (accessed: 2.06.2021)

24. Parshykova A. Supporting small and medium-sized businesses in the world (review of tools and policies) (in Ukrainian). URL: https://is.gd/7qxTt9 (accessed: 27.05.2021)

25. All about \# COVID19 for small and medium businesses.URL: https://sme.gov.ua/covid19/ (accessed: 2.06.2021)

26. Socio-Economic Implications of COVID-19 Pandemic in South Asia: Emerging Risks and Growing Challenges / Rasul G. el.al. Frontiers in Sociology. 2021. Vol. 6. Paper 629693. DOI: 10.3389/fsoc.2021.629693.

27. Facing and responding to the COVID-19 threat - an empirical examination of MSMEs / Duarte Alonso A. et.al. European Business Review. 2021. Vol. ahead-of-print No. ahead-of-print. DOI: https:/ / doi.org/10.1108/EBR-09-2020-0231 
28. Sylvana G. B. Risk Mitigation for Small and Medium Sized Enterprises (SMEs) in the Middle of Volatility in the World's Economy Condition. OISAA Journal of Indonesia Emas. 2021. Vol. 4. Pp. 34-39.

29. Turaev I., Ganiev F. Management Strategy of Small and Medium Enterprises during the Pandemic Covid-19. Journal La Bisecoman, 2021. Vol. 2(1). Pp. 7-12. DOI: https://doi.org/10.37899/journallabisecoman.v2i1.321. URL: https://is.gd/10BYi (accessed: 4.06.2021)

30. Shevchenko-Perepolkina R. Ways of small business development in Covid-19. Market Infrastructure. 2020. Vol. 49. Pp. 147-151 (in Ukrainian). URL: https://cutt.ly/ AnmleMa (accessed: 4.06.2021)

31. Hadiyati E., Hendrasto F. Entrepreneurial Marketing Strategy of Micro, Small and Medium Enterprises in Pandemic Covid-19 Era. International Journal of Economics \& Business Administration (IJEBA). 2021. Vol. 0(2). Pp. 178-191. DOI: https://doi.org/10.35808/ijeba/696

32. Papadopoulos T., Baltas K. N., Balta M. E. The use of digital technologies by small and medium enterprises during COVID-19: Implications for theory and practice. International Journal of Information Management. 2020. Vol. 55. Paper 102192

33. Gregurec I., Tomishich Furjan M., Tomishich-Pupek, K. The Impact of COVID-19 on Sustainable Business Models in SMEs. Sustainability. 2021. Vol. 13. No. 3. Paper 1098. DOI: https://doi.org/10.3390/su13031098

34. Pedauga L., Saez F., Delgado-Márquez B.L. Macroeconomic lockdown and SMEs: the impact of the COVID-19 pandemic in Spain. Small Business Economics. 2021. DOI: https://doi.org/10.1007/s11187-021-00476-7. URL: https://is.gd/IATEU6 (accessed: 28.05.2021)

35. Aftab R., Naveed M., Hanif S. An analysis of Covid-19 implications for SMEs in Pakistan. Journal of Chinese Economic and Foreign Trade Studies. 2021. Vol. 14. No. 1. Pp. 74-88. DOI: https://doi.org/10.1108/JCEFTS-08-2020-0054

36. Osarumwense R., Obose A. Impact of Coronavirus (Covid-19) Pandemic on Small and Medium Businesses in Edo State. European Journal of Business and Management. 2021. Vol.13, No. 8. Pp. 22-30. DOI: 10.7176/EJBM/13-8-03. URL: https://is.gd/G02qvK (accessed: 4.06.2021)

37. Risk Assessment of the SME Sector Operations during the COVID-19 Pandemic / Grondys K. et.al. International Journal of Environmental Research and Public Health. 2021. Vol. 18. No. 8. Paper 4183. DOI: https://doi.org/10.3390/ijerph18084183

38. Munandar Tb. Ai. Analysis of Regional Development Disparity with Clustering Technique Based Perspective. International Journal of Advanced Research in Computer Science. 2015. Vol. 6 (1). Pp. 137-141

39. Munandar Tb. Ai, Musdholifah A. A., Arsyad L. Multiview Hierarchical Agglomerative Clustering for Identification of Development Gap and Regional Potential Sector. Journal of Computer Science. 2018. Vol. 14 (1). Pp. 81-91.

40. Hryhoruk P., Khrushch N., Grygoruk S. The Rating Model of Ukraine's Regions According to the Level of Economic Development. Periodicals of Engineering and Natural Sciences. 2019. Vol 7. No 2. Pp. 712-722. DOI: 10.21533/pen.v7i2.555.g338 URL: https://is.gd/DSx7Fz (accessed: 4.06.2021)

41. Ministry for Communities and Territories Development of Ukraine. Rating assessment of regions (in Ukrainian). URL: https://cutt.ly/olpWxkF. (accessed: 4.06.2021)

42. Igor Petrashko: Only for the first 3 working days of 2021 applications for UAH 800 million were submitted under the program "Affordable loans 5-7-9\%" (in Ukrainian). URL: https://is.gd/FhwFWi (accessed: 22.05.2021)

43. The first COVID-19-Business Clinics to support small and medium-sized businesses in Ukraine were launched (in Ukrainian). URL: https://is.gd/2G8Gac (accessed: 8.06.2021)

44. State Strategy for Regional Development for 2021-2027 (in Ukrainian). https://cutt.ly/8lpQMyk (accessed: 8.06.2021)

\title{
ДОСЛІДЖЕННЯ СТРУКТУРНИХ ЗРУШЕНЬ ВНАСЛІДОК ПАНДЕМІЇ СОVID-19 3А ПОКАЗНИКАМИ ДІЯЛЬНОСТІ МАЛИХ ТА СЕРЕДНІХ ПІДПРИЕМСТВ
}

\author{
НІЛА ХРУЩ \\ Хмельницький національний університет
}

\begin{abstract}
Підприємства малого і середнъого бізнесу є важливою складовою економічної системи більшості крайн світу, забезпечуючи зайнятість і доходи значної частки населення, економічну та соціальну трансформацію. При цьому вони не так залежні від кон'юнктури зовнішніх ринків, валютних коливань, гнучко адаптуються до мінливих умов ринкового середовища. Важливу роль підприємства малого і середнього бізнесу відіграють $і$ у вітчизняній економіці. Вони формують відчутну частину доходів місиевих бюджетів, забезпечуючи створення нових робочих місиь; вирішення проблеми подолання безробіття, щз пов'язано зі зменшенням кількості та чисельноті великих підприємств; здійснюють підтримку та розвиток середнього класу в суспільстві; швидке пристосування до ринкових змін, нових обставин. Пандемія COVID-19 різними способами уповільила діяльність підприємств різного розміру та типу. Найбільще постраждали малі і середні підприємства, що працюють у різних секторах економіки. Це дослідження має на меті дослідити вплив пандемії COVID-19 на функиіонування малих і середніх підприємств та зміну регіональної структури за показниками їх діяьності. Ми застосували дослідницьку методологію з критичним оглядом наявної літератури для даного сектору економіки. Для вирімення поставлених завдань нами використаний метод кластеризацї к-теапs, який являє собою ітераційну процедуру пошуку групувань об'єктів у просторі ознак. В результаті проведених розрахунків регіони України були розподілені між чотирма кластерами. Нами надана характеристика кожного кластера. Дослідження показали, що у 2020році не відбулось істотних змін у кластерній структурі регіонів. Це призводить до висновку, що вплив пандемії однаково проявився у всіх регіонах. Нами також проаналізовані заходи уряду крайни, , спрямовані на підтримку діялності малих і середніх підприємств, зменшення втрат та ризиків припинення діялності від обмежувальних заходів.
\end{abstract}

Ключові слова: Cоуіd-19, малі і середні підприємства, регіональна структура, кластеризація, метод $k$-теапs. 